\title{
Myanmar's education and national identity
}

\author{
Zuo Ya* \\ School of History and Archives, School of International \\ Languages and Cultures School \\ International Business School \\ Yunnan University of Finance and Economics \\ Kunming, China
}

zuo.ya@qq.com

\author{
Yang Juwei \\ School of History and Archives \\ Yunnan University of Finance and Economics \\ Kunming, China \\ 1183500060@qq.com
}

\begin{abstract}
For a nation state, education has been seen as a fundamental and effective approach to maintain a sense of national identity for a long time. For most nation states, multi-ethnicity is recognized as the main character; due to this, many scholars begin to show their concern about how to promote the civic consciousness and national identity through education. Myanmar is a multi-ethnic state, which has long been abused by ethnic issues. Therefore, education may play an important role in conciliating ethnic conflicts and strengthening the national cohesion and finally, maintaining the governmental legitimacy. This article will briefly review Myanmar's educational history in three historical periods and discuss the influences on national identity among the people of Myanmar. Furthermore, this article will analyze the Myanmar's recent education reform and accordingly, some suggestions are given.
\end{abstract}

\section{Keywords—Myanmar; education; national identity}

\section{INTRODUCTION}

Generally, education can meet the needs of both moral and ethical inculcation along with the learning of knowledge and skills. The former will build up the core value of a society and the latter will cultivate talents. Education has the power to convert the instructed through a rational way and at the same time, it spurs for action according to what the instructed have learnt.

Myanmar is the home to diverse ethnic minority peoples, thus, it is called the "paradise of anthropologists". In Myanmar, Burmans comprise just $68 \%$ of the population and the rest are ethnic peoples and immigrants [1]. In history, wars constantly came up between ethnic minorities and Burmans. During the colonial period, the situation worsened as the British government launched the policy of "divide and rule", which deepened the ethnic hostility and estrangement. In March this year, when the National League For Democracy took office, the new government started to make preparations for the " $21 \mathrm{st}$ Century Panglong Conference". In order to bring about the political dialogue between the government and the leaders of ethnic minorities, the government announced that they will take all-inclusive policy to those who will be willing to attend this conference. Certainly, this conference will create a new political landscape for NLD and this nation, but it cannot be overlooked that even if ethnic leaders sign the Nationwide Ceasefire Agreement, the bygone confrontation and hostility cannot be erased at once.

How to solve the ethnic problems and to build up a united nation are worth studying and many scholars do have done quite in this field. Some valuable works on Myanmar's nation building are Doctor Liu Wu's work Myanmar's Nation-building Since 1988, Doctor Zhong Guifeng's work A Study on the Inter-ethnic Relations Governance in the Process of Myanmar's Nation-state Construction, Kang Youliang's master thesis Study on the Transformation of Burma Politics Since 1988 and Qu Mengchen's master thesis Myanmar's Modernization after Independence: Political Development and Ethnic Problems. Works on ethnic problems are Wang Feng's master thesis The Constitutional Reform of Burma and the Founding State Movement of Karens-The Triangular Relationship among the British, Burmese and Karens, Zhang Zhixue's master thesis The Bloom and Decline on Burmese Karen Nation-separatism Movement. Some famous works written by overseas scholars are Martin Smith's Burma Insurgency and the Politics of Ethnicity and E. R. Leach's Political Systems of Highland Burma. In the field of education study, the achievement is also impressive, such as Doctor Liu Quan's work Integration and Differentiation: The Internal Relations in the Ethnic Chinese Community of Mandalay from the Perspective of Overseas Chinese Education, foreign scholars Marie Lall's work Evolving Education in Myanmar: the Interplay of State, Business and the Community and Han Tin's work Myanmar Education: Challenges, Prospects and Options. One noticeable aspect of these works is that scholars do not connect national identity with education in Myanmar's study. On the contrary, some scholars worried about the domestic problem on the relationship between national identity and education decades ago, for instance, Robert M. Stamp's work Canadian Education and the National Identity, published in 1971; Graham Pike's work Global Education and National Identity: In Pursuit of Meaning, published in 2000 and Audrey Osler and Hugh Starkey's work Citizenship Education and National Identities in France and England: Inclusive or Exclusive? published in 2001. At this point, it is of significance to discuss the influence on Myanmar's national identity from the perspective of education.

*Corresponding author 


\section{The History of EdUCATION IN THREE PERIODS AND THEIR INFLUENCES ON NATIONAL IDENTITY}

\section{A. The history of education in three periods}

1) Education and national identity in the feudal period

Myanmar's educational development experienced three historical periods namely, the feudal period, the British colonial period and the period of military regime. During the feudal period, Burman culture and Buddhist culture were the mainstreams in ancient Myanmar. Burman culture and Buddhist culture were delicately woven together to strengthen Burman's national sense of pride, and to construct the social norms and standards of behaviors. Many Buddhist stories were translated into Burmese to encourage the wide-spread of Buddhism and Burmese. Little by little Burmese became the official language and Buddhism was also rooted in the heart of Burman people.

Monastic education was the sole access to education at that time [2]. Reciting scriptures was the learning method for monastics, and curriculums of basic literacy and calculation were offered to children of school age. Under the protection of kings, monastics could get promotion only if they respect and revere Buddha and doctrines. And those who were selected to study and be purified in Ceylon would be promoted by the time they returned. For monastics, this was an ideal approach to realize their life and political value. Although skills training was neglected, kings could stay in power and monastics could maintain social status through moral and ethical education.

In the feudal period, the education system, teaching methods and the content played an important role in forming the social value and strengthening a sense of cohesion among Burman people. Binding the Buddhism together with Burmese, Burman people acquired a sense of ethnic identity. Still, the inevitable defects were obvious. The national identity grew with a monarch at its core. The words and deeds of a king ought to accord with the ethical system of Buddhism, otherwise, his legitimacy would be questioned. Students learnt the moral and ethical doctrines from monastic education but what they could do was to give advice to the king instead of reshaping the structure of the state. Furthermore, as the chance of promotion was under control by the king, it is impossible for monastic education to teach students with ideas of new national institution.

\section{2) Education and national identity in the colonial period}

The British launched war in Myanmar for three times and annexed it. The initial purpose of annexation was to seek economic interests and security. For the sake of convenience, British government divided Myanmar into two distinctive areas-Ministerial Burma and the Frontier Areas respectively [3]. In Ministerial Burma, colonial government established the modern national administrative system and opened several new sectors. In the Frontier Areas, however, hereditary headmen were allowed to administrate their lands under the guidance of indirect governance policy. In these areas, the traditional customs were fully preserved. This policy inevitably widened the gap of cultural and knowledge development between the Frontier Areas and Ministerial Burma.
In order to guarantee the quality of employees hired by the colonial government, the Education Bureau was set up in 1866 For the purpose to replace the monarchy with the modern government, colonial government established secular schools and conducted skill-training curriculums to train lower civil servants. Monastic education confronted the great challenge from those secular schools. Rich families sent their children to state-run schools, where skill-training courses such as English, mathematics, geography, hygiene and nursing became popular majors [4]. At first, the colonial government did not set Burmese major in case Burman people rallied and rebelled. Alternatively, English learning gained much of a priority so as to highlight its importance and to widen difference among social classes. Ideas of monastic education did not mesh with the need of the colonial government, though the colonial government did make an effort to set some secular courses in monastic schools, most monastic schools declined this arrangement. Without the backup of the authority and chances for promotion, monastic education languished hopelessly. In contrast to the prosperity of secular education in cities, people in rural areas followed the tradition of sending their children to monastic schools. Rote learning and Buddhist doctrines remained the core of teaching, which became the symbol of fighting against colonialism in the years to come. Due to the lack of economic and political support, the quality of monastic education went worse and worse and the gap between the educated from cities and countries grew wider and wider.

In the colonial period, various schools sprang up and students studying in secular schools were able to absorb the modern scientific knowledge and expertise while those studying in monastic schools were not. Through the learning of the western culture, some Myanmar people had an opportunity to compare and rethink their culture. In the process of comparison and contrast, new social value generated along with new identities. Monastic education was pushed back to countries because unlike those monarchs, the British government needn't Buddhism to recognize its political legitimacy. One advantage of colonial education policy was that a unified and standardized education system helped to normalize and integrate schools in Myanmar. The will of the colonial government would be better carried out through the designing and implementing of education policies. For some people, the idea of karma instilled by Buddhist doctrines was given up by the combination of study and work. Parents preferring secular schools hoped that their children could work for the colonial government and gain social status after graduation.

Yet, the decline of monastic schools indicated the disadvantage of colonial education system on the development of Myanmar culture. The colonial government didn't mean to build an independent state of Myanmar, and thus they had no idea to form the social value through education, especially monastic education. Secular education substituted monastic education in Ministerial Burma, but in the Frontier Areas headmen were still in charge. That was to say, the traditional education system, undertaken by monastic schools, was still prevailing. In many aspects, such as the investment and teachers, these monastic schools couldn't compare with those secular schools in Ministerial Burma. Accordingly, unlike 
students from rich families in urban areas, students from poor families in rural areas had few chances to receive advanced education and find positions in governmental agencies. As a matter of fact, many of students dropped out after learning some basic life skills. Despite all this, traditional social values and cultural heritage were inherited and passed on from generation to generation in rural areas. On the contrary, secular education in Ministerial Burma produced many social elites, who approved of the administrative system but won't be entitled to seek for higher position only because of race. It was the colonial administrative system that made these elites to dream of liberating from British colonial government.

\section{3) Education and national identity in the colonial period}

After Myanmar independence in 1948, Burman elites adopted the western parliamentary democracy. But then, general Ne Win seized power in 1962 and Myanmar headed a military dictatorship. Impacted by the system of western government in colonial period, students detested the rule of the military regime, demonstrated several times and request to change the situation. In fear of student movements, the military regime resorted to extreme measures to limit students to participate in politics.

The government banned famous Yangon University and Mandalay University. Later, it established hundreds of local institutions throughout the country to discourage students' assemblies. In investment, the government cut spending to hinder the operation of these institutions. Low salaries dispelled the dream of being a teacher for many young graduates and many poor families couldn't afford for the tuition fee, so their children dropped out. Even if some students could finish university studies, they had trouble looking for jobs due to the unreasonable academic majors setting.

In class, memorizing and reciting were consistent teaching methods. The abilities of reasoning and thinking independently were deliberately suppressed, with the consequence that the class was lifeless and teachers performed carefully in case something went wrong. Furthermore, as teachers were imposed to supervise their students and hold responsible for them, the harmonious relationship between a teacher and his students was destroyed.

In the Frontier Areas, operational funds came from parents and donation of society. The hardship of rural monastic schools was the elephant in the room. Another obstacle made by military regime was the implementation of bilingual education - Burmese and English. Ethnic students were shut out of the state universities and fine jobs by the discriminatory policy. In turn, ethnic students chose to give up the state universities and primary aged children were taught by their elders naturally.

Apart from this, because of the influx of Indian and Chinese migrants, along with the arrival of Islam and Christianity in the British colonial time, Myanmar's society became more diverse and social contradictions became more complex. The military regime made excuse $\mathrm{s}$ to prevent immigrants and ethnic people from printing their own textbooks [5]. Both immigrant and ethnic students dissented from the educational policy, which articulated the intention of assimilation. What military regime had done was unacceptable and intolerable, some students organized secret societies and some escaped to the border where books about western politics might be obtained sometimes.

Surely, the military regime confronted a severe identity crisis produced by itself. Its education policy did not fool its people, instead, more and more people expressed their discontent about a chain of problems caused by the education system and began to question the legitimacy of military regime. Using English and Burmese only in class and compelling ethnic students to learn the textbook provided by military regime stirred up the dissatisfaction among ethnic minorities and immigrants. In response, they taught their children by themselves in the goal of preserving their traditions and defending against the cultural erosion of military regime. Monastic education maintained not only the basic education in rural areas, but also the traditional beliefs among ordinary people. The loss of support from monastics implied the loss of legitimacy. In the course of the military regime, the government failed to create the cultural identity and the identity of constitutional institution. Rather, it built an ethnic identity among minorities and immigrants, which caused serious identity crisis. Ironically, it was the time when people in Myanmar were longing for collaboration to against the rule of military regime.

\section{B. The Influences on National Identity}

The education system in feudal period indeed set up a sort of identity through the support of Buddhism and Burman culture. From this identity, Burman people were aware of their distinctive characters and were proud of the history they created. This identity could be seen as a kind of ethnic identity. Nevertheless, the footstone of this identity was allegiance to a certain person. Obviously, this kind of relationship could break up in case of the death of the person or the betrayal for interest. In the colonial period, the colonial government had no purpose to create a nation so that it was impossible for the government to develop a common value and encourage integration. Like Martin Smith quotedMichael Aung Thwin as saying "the British gave Myanmar order without meaning". Still, education in Ministerial Burma did foster a group of knowledgeable young Burmans, and at the same time, the blockage of advancing into the upper class successfully stirred up their national sentiment. To some extent, under the control of colonial government, the concept of multi-national state and the recognition of the constitutional institution rooted in the mind of Myanmar elites. Unfortunately, the military regime was unable to maintain the good momentum of political development. Not only that, it caused a variety of identity crises even threatened its rule.

\section{THE CURRENT EDUCATION CONDITION AND ITS INFLUENCES ON FUTURE NATIONAL IDENTITY}

\section{A. The current education condition}

Since 2010, the change of education condition in Myanmar is encouraging. Government increased investment and cooperated with United Nations International Children's Emergency Fund (UNICEF), the Multi-Donor Education Fund (MDEF) [6] and some non-governmental organizations to 
launch a Comprehensive Education Sector Review (CESR) and to form the Education Promotion Implementation Committee(EPIC). Through a coherent three phase processes, government will complete its education reform programs and develop an integrated educational system [7]. These reforms bring hope and expectations to Myanmar people but looking down upon the difficulties is not advisable.

In the first place, the educational budget is still insufficient to hold the satisfactory operation of all-level schools in urban and rural areas. In the second place, there isn't a comprehensive system to organically combine schools of various types at various levels throughout the country. In the third place, the inefficiency of government sectors leads to the difficulties in policy implementation. One example is that in 1992, Myanmar Education Research Board criticized Myanmar's school examination system for its elitism, which was a relic of the colonial period that still dominated the education system. High failure rate led to exam-oriented education [8]. Although the exam-oriented education is condemned by the relevant sectors and the parents of examinees, the acceptance rate has remained around 35\% from 2010 to 2015 . This year, the acceptance rate unexpectedly drops to $29.92 \%$ [9]. Last but not least, centralized power centralizes in a few sectors extinguished the enthusiasm of schools and institutions. From top to bottom, the faculty and staff of a school all serve for the government, but those governors seldom do field work at all.

\section{$B$. The influences on future national identity}

Without doubt, these reforms will help to better understand Myanmar's education condition. Schools in remote areas may receive more money to improve the teaching environment and teaching equipment, and ethnic minorities may benefit from this reform. Meanwhile, through reforms, various schools and institutions will be regulated, which will enhance their credibility and normalization. Correspondingly, their students will feel a sense of belongingness and then, enhance their national identity.

Yet, as former government ignored the actual demands and national pride of minorities and obliged them to abandon their languages and traditions, they may take an attitude of skepticism on the reforms and equate these reforms with assimilation means. Moreover, low efficiency of the government will lose the confidence in these reforms among the people.

\section{SOME SUGgestions On MyanMaR's EdUCATION}

Surely, the education reform is helpful for the enhancement of national identity in Myanmar, but in practice, the following aspects will be given great attention: first, when implementing reform programs, ethnic minority areas should be put in the first place. Second, respecting ethnic minorities' culture and traditions should be indeed fulfilled. For the government, the anxiety of separation caused by encouraging minorities to study their mother languages and learn about their heroes and historical events is unwarranted. Instead, it will instill minorities' pride and belonging. Third, the government need to [10] balance the skills training and the liberal arts education. Though Buddhism doesn't officially become the state religion, its influence in Myanmar is significantly and permanently. The assistance of the development of Buddhism will benefit for the social stability. Meanwhile, it is necessary to pay much attention to the development of Islam and Christianity. From this point of view, education is suggested as one of the peaceful methods to ease religious tensions.

\section{CONCLUSION}

Myanmar's education experienced several historical periods, which greatly impacted on the modern education system. Those who took advantage of education for their political ends should be responsible for the serious problems of education, but the new government has noticed this issue and started launching the reform. Today, overemphasizing "multicultural society" may cause unnecessary worry of national identity crisis, but for Myanmar, a nation with diverse minority peoples and religious faiths, admitting the existence of multiculturalism and respecting it might be the proper attitude towards national identity.

\section{ACKNOWLEDGMENT}

Frankly speaking, it's my first time to write academic article on Myanmar's education. I learnt a lot after reading relative books and articles. From their works I am aware of the importance of education in national identity for a nation state. Therefore, I will thank these writers who did make great contribution on Myanmar's study. And I am grateful to professor He Pin and Sun Laichen. You are my important supervisors who guide me to do the research in this field. I would like to thank Mr. Yang Juwei for your helpful suggestions and consistent support. Also, my gratitude will go to Yunnan University and Yunnan University of Finance and Economics. The two universities supply the perfect platform for my research. Finally, I will thank to my family, without your support, I would not immerse myself in academic research.

\section{REFERENCE}

[1] "Myanmar-Camilo Guerrero-Higher education case studies Myanmar," The Economist Intelligence Unit Limited, 2014, pp. 3.

[2] S.D. He, "Burman history," Yunnan People's Publishing House, 2015, pp. 70 .

[3] M. Smith, "Burma: insurgency and the politics of ethnicity," Zed Books, 1991, pp. 42.

[4] J. Zhao, "The development of Burman education during the colonial period," Oriental Forum, vol. 5, 2013, pp.45.

[5] C. Fink, "Living silence in Burma - surviving under military rule," Zed Books, 2009, pp. 193-195.

[6] "Myanmar Comprehensive Education Sector Review," 2013.

[7] UN Children's Fund, "Comprehensive Education Sector Review in Myanmar Sets the Path for Improving Quality of Education," Nov 2016.

[8] M. Hayden and R. Martin, "Recovery of the education system in Myanmar," Journal of International and Comparative Education, vol. 2, 2013, pp. 52.

[9] Myanmar golden phoenix, July, 2016. 